\title{
Crude Glycerol from Biodiesel Industry as Substrate for Biosurfactant Production by Bacillus subtilis ATCC 6633
}

\author{
Marylane de Sousa ${ }^{1}$, Iuri Torquato Dantas ${ }^{1}$, Anne Kamilly Nogueira Felix ${ }^{1}$, Hosiberto \\ Batista de Sant'Ana ${ }^{1}$, Vânia Maria Maciel Melo ${ }^{2}$ and Luciana Rocha Barros Gonçalves ${ }^{1 *}$ \\ ${ }^{I}$ Departamento de Engenharia Química; Universidade Federal do Ceará; Fortaleza - CE - Brasil. ${ }^{2}$ Departamento \\ de Biologia; Universidade Federal do Ceará; Fortaleza - CE - Brasil
}

\begin{abstract}
Glycerol, a co-product of the biodiesel industry, may be a suitable raw material for the production of high addedvalue compounds by the microorganisms. This study aimed to use the glycerol obtained from the biodiesel production process as the main carbon source for biosurfactant production by Bacillus subtilis ATCC 6633. Results indicated that the strain lowered the surface tension of the cell-free fermented broth to $31.5 \pm 1.6 \mathrm{mN} / \mathrm{m}$, indicating the production of biosurfactant. The critical micelle concentration $(C M C=33.6 \mathrm{mN} / \mathrm{m})$ obtained was similar to the previously reported for biossurfactants isolated from other Bacillus. The produced biosurfactant was able to emulsify n-hexadecane and soybean oil.
\end{abstract}

Key words: Biosurfactant, Biodiesel, Glycerol and Surfactin

\section{INTRODUCTION}

Biosurfactants are biological surface-active compounds released by the microorganisms that can have some influence on the interfaces (Salihu et al. 2009). They are proteins with detergent, emulsifier, and surfactant power to lower the surface tension of water and other solvents, and have potential applications in environmental uses such as organic pollutants treatment and oil recovery (Neves et al. 2007). Microbial surfactants are produced primarily by the bacteria. However, they are also produced by the yeasts and fungi (Fiechter 1992). The production of biosurfactants is often related to the consumption of hydrocarbons, including oily residues, and occurs during the exponential cellular growth (Neves et al. 2007). But they can also be produced from the sugars (sucrose, glucose and lactose), glycerol, vegetable oils, or starch as carbon sources (Cirigliano and Carman 1984; GuerraSantos et al. 1984; Makkar and Cameotra 2002; Reis et al. 2004; Amaral et al. 2006; Giro et al. 2009). Those amphiphilic compounds are capable to reduce surface and interfacial tension between the two liquids (Bicca et al. 1999) and they have important characteristics when compared to synthetic surfactants, such as high biodegradability, low toxicity, high surface activity, solubility in alkaline water, thermal stability, resistance to high saline concentrations and stability against variations of $\mathrm{pH}$ (Kim et al. 2002). Another advantage is that biosurfactants can be synthesized from the renewable substrates. They also have high chemical diversity, allowing specific applications for each particular case (Desai and Banat 1997).

The largest market for the biosurfactants is in the oil industry, where they are used in the production of oil, or incorporated into the formulations of

*Author for correspondence: $\operatorname{lrg} @$ ufc.br 
lubricating oils (Van Dyke et al. 1991). Other applications include bioremediation and dispersion of oil spills, removal and mobilization of residual oil in storage tanks, as well as in enhanced oil recoveries (Nitschke and Pastore 2002).

The microbial surfactants are not yet capable for competing economically with the chemical surfactants in the market, mainly due to its high costs (Pruthi 1997; Davis et al. 1999). The production of biosurfactants is a great challenge in biotechnological processes in the present economy. The success of its production depends on the development of an industrial bioprocess based on low cost raw materials, which may not exceed 10 to $30 \%$ of the cost of the final product (Cameotra and Makkar 1998). Thus, the use of a co-product from the biodiesel production (glycerol) as a carbon source could be a good alternative for the synthesis of biosurfactants by fermentation, since glycerol has a low market value due to the presence of various impurities in it (Thompson et al. 2006). Furthermore, the expansion of biodiesel production has made the price of glycerol to fall gradually, which may help to reduce the cost of biosurfactants production.

The purpose of the present work was to use the glycerol obtained from the biodiesel production process as the main carbon source for biosurfactant synthesis by Bacillus subtilis ATCC 6633 , with the goal of lowering the production costs associated with surfactin production. This stain has been reported for the production of biosurfactants from different carbon sources (Reis et al. 2004).

\section{MATERIALS AND METHODS}

\section{Microorganism}

B. subtilis ATCC6633, obtained from André Tosello Tropical Foundation - Campinas, SP, Brazil, was maintained on APGE medium, consisting of $(\mathrm{g} / \mathrm{L}) 5.0$ peptone, 5.0 glucose, 2.5 yeast extract and 15.0 agar at $4^{\circ} \mathrm{C}$ and subcultured monthly.

\section{Raw material}

Glycerol used in this work resulted from the transesterification of soybean oil by methanol in alkaline medium $(\mathrm{NaOH})$. Pre-treated glycerol (neutralized with $\mathrm{H}_{2} \mathrm{SO}_{4}$ and methanol evaporated) was provided by Empresa Brasileira de Bioenergia Ind. Com Ltd. (EBB, Ceará, Brazil).

\section{Culture medium and cultivation conditions Inoculum preparation}

The microorganism was inoculated onto APGE plates and incubated at $30^{\circ} \mathrm{C}$ for $24 \mathrm{~h}$. From this, three colonies were transferred to $250-\mathrm{mL}$ Erlenmeyer flasks, containing $50 \mathrm{~mL}$ of medium (PGE), composed of (g/L) 5.0 peptone, 5.0 glucose, 2.5 yeast extract, sterilized at $121^{\circ} \mathrm{C}$ for 15 minutes in the autoclave. The flasks were incubated in a rotary shaker (Tecnal - TE240, São Paulo, Brazil) at $180 \mathrm{rpm}$ and $30^{\circ} \mathrm{C}$ for $24 \mathrm{~h}$. Afterwards, the optical density (OD) of this culture was adjusted to $0.1-0.2$ at $600 \mathrm{~nm}$.

\section{Culture medium}

A defined mineral medium was firstly prepared according to Sar and Rosemberg (1983) with the following composition $(\mathrm{g} / \mathrm{L}): \mathrm{K}_{2} \mathrm{HPO}_{4}$ 13.99, $\mathrm{KH}_{2} \mathrm{PO}_{4}$ 6.0, $\mathrm{MgSO}_{4} .7 \mathrm{H}_{2} \mathrm{O}$ 0.2, $\left(\mathrm{NH}_{4}\right)_{2} . \mathrm{SO}_{4} 4.0$, and $0.04 \%$ yeast extract. The mineral medium was sterilized at $110^{\circ} \mathrm{C}$ for 10 minutes. Then $0.1 \%$ $(\mathrm{v} / \mathrm{v})$ of a micronutrient solution, consisting of $(\mathrm{g} / \mathrm{L}) \quad$ EDTA $2.5 \mathrm{~g}, \quad \mathrm{ZnSO}_{4} .7 \mathrm{H}_{2} \mathrm{O} \quad 10.95$, $\mathrm{FeSO}_{4} .7 \mathrm{H}_{2} \mathrm{O}$ 5.0, $\mathrm{MnSO}_{4} \cdot \mathrm{H}_{2} \mathrm{O} 1.54, \mathrm{CuSO} .5 \mathrm{H}_{2} \mathrm{O}$ $0.392, \mathrm{Co}\left(\mathrm{NO}_{3}\right)_{2} \cdot 6 \mathrm{H}_{2} \mathrm{O} 0.25$ and $\mathrm{Na}_{2} \mathrm{~B}_{4} \mathrm{O}_{7} .10 \mathrm{H}_{2} \mathrm{O}$ 0.177 , previously sterilized by filtration was added (Morán et al. 2000). Finally, 2\% (v / v) of glycerol, previously sterilized at $121{ }^{\circ} \mathrm{C}$ for 15 min, was added to the medium.

\section{Batch fermentation}

All the assays were conducted in Erlenmeyer flasks of $250 \mathrm{~mL}$ with $50 \mathrm{~mL}$ of culture medium on a rotary shaker (TE240 - Tecnal, São Paulo, Brazil) at $180 \mathrm{rpm}$ and $30^{\circ} \mathrm{C}$. The medium was inoculated $(1 \%, \mathrm{v} / \mathrm{v})$ and incubated for $72 \mathrm{~h}$ in isothermal conditions. Samples $(50 \mathrm{~mL})$ were collected at pre-defined intervals of time and analysed for biomass, substrate and surfactin concentrations, emulsification index $\left(\mathrm{E}_{24}\right)$, surface tension and critical micelle concentration (CMC).

\section{Analytical methods \\ Emulsification index $\left(E_{24}\right)$}

Emulsification index was determined according to Cooper and Goldenberg (1987), with slight modifications: $2.0 \mathrm{~mL}$ of cell-free supernatant was added to $2.0 \mathrm{~mL}$ of different hydrophobic sources (soy oil, kerosene, N-hexadecane) and the mixture was homogenized in a vortex-type stirrer for 2 
min. After $24 \mathrm{~h}$, the height of the emulsion layer was measured. The emulsifying activity $\left(\mathrm{E}_{24}\right)$ was calculated using the equation 1 (Desai and Banat, 1997).

$E_{24}(\%)=\frac{H_{E L}}{H_{S}} * 100$

Where $\mathrm{H}_{\mathrm{EL}}$ is the height of the emulsion layer and $\mathrm{H}_{\mathrm{S}}$ is the height of total solution.

\section{Surface tension}

Surface tension was determined in the cell-free fermented broth using a tensiometer (Krüss K6) at $25^{\circ} \mathrm{C}$, according to the De Nöuy ring method (Zajic and Seffens 1984).

\section{Emulsifying activity}

Emulsification activity was determined in accordance with the methodology described by Cirigliano and Carman (1985), with slight modifications (Giro et al. 2009). The samples were filtered through a Millipore $0.45 \mu \mathrm{m}$ membrane and the filtrate $(1.0 \mathrm{~mL})$ was placed in glass tubes $(15$ by $125 \mathrm{~mm})$ and diluted with 1.0 $\mathrm{mL}$ of $0.1 \mathrm{M}$ sodium acetate buffer $(\mathrm{pH} 3.6)$. Then, $0.5 \mathrm{~mL}$ of kerosene was added to the tube, which was homogenized in a vortex-type stirrer. The resulting emulsion remained at rest for 10 minutes, and then the aqueous phase absorbance was measured in spectrophotometer (Spectronic ${ }^{\circledR}$ 20 Genesys) at $540 \mathrm{~nm}$. One unit of emulsifying activity was defined as the amount of biosurfactant that resulted in an absorbance of 1.0 at $540 \mathrm{~nm}\left(\mathrm{~A}_{540}\right)$ under the conditions described above.

\section{Biomass}

Cell growth was determined by measuring the optical density of samples, using a UV-visible spectrophotometer (20 Genesis, BR) at $600 \mathrm{~nm}$. Cell concentration was determined using a calibration curve that related the values of optical density and dry weight (Makkar and Cameotra 1998).

\section{Surfactin concentration}

Surfactin concentration was determined using a Waters high-performance-liquid chromatographer equipped with a UV detector (Model 2487, Waters), at $205 \mathrm{~nm}$, and a Symmetry $\mathrm{C}_{18}$ column (150 x $4.6 \mathrm{~mm}, 5 \mu \mathrm{m}$, Waters, Ireland). The mobile phase consisted of $20 \% \quad(\mathrm{v} / \mathrm{v})$ trifluoroacetic acid $(3.8 \mathrm{mM})$ and $80 \%(\mathrm{v} / \mathrm{v})$ acetonitrile. The elution rate was $1.0 \mathrm{~mL} / \mathrm{min}$ at $30^{\circ} \mathrm{C}$ and the sample size was $20 \mu \mathrm{L}$. The identity of the purified surfactin was obtained by using the commercially available $95 \%$ pure surfactin (Sigma-Aldrich) as the reference compound (Yeh et al. 2005).

\section{Glycerol concentration}

Glycerol concentration was determined using a Waters high-performance-liquid chromatography equipped with a refractive index detector and a Supelcogel $\mathrm{C} 610 \mathrm{H}$ column $(30 \mathrm{~cm} \times 7.8 \mathrm{~mm})$. $\mathrm{H}_{3} \mathrm{PO}_{4}(0.1 \%)$ in ultra-pure water (MiliQ) was used as mobile phase with the flow rate of 0.5 $\mathrm{mL} / \mathrm{min}$ at $30^{\circ} \mathrm{C}$ and volume of injection was 20 $\mu \mathrm{L}$ (Sousa et al. 2012).

\section{Determination of the critical micellar concentration}

Different concentrations of the produced biosurfactant were obtained by performing several dilutions of the cell-free fermented broth, containing surfactin produced after $48 \mathrm{~h}$ of fermentation (Santa Anna et al. 2002). Superficial tension of the resulting solutions was measured at room temperature, as described above. The CMC was determined by plotting the surface tensions as a function of the logarithm of surfactin concentration and it was found at the point of intersection between the two lines that best fit the pre- and post-CMC data (Gudina et al. 2010).

\section{RESULTS AND DISCUSSION}

Biosurfactant production by $B$. subtilis ATCC6633 cultivated in mineral media supplemented with Glycerol.

The effect of a semi-defined medium, mineral medium using glycerol as carbon source on surfactin production by $B$. subtilis ATCC6633 was examined in this work by monitoring the changes in cell growth, glycerol consumption and surfactin concentration. The results as shown in Figure 1 revealed that the strain was able grow and to produce surfactin from glycerol. After $48 \mathrm{~h}$ of cultivation, there was an increased in the production of surfactin, reaching a concentration of $158.14 \mathrm{mg} / \mathrm{L}$ at $72 \mathrm{~h}$ of fermentation. At the same time, an increase in cell concentration was observed, reaching $1.69 \mathrm{~g} / \mathrm{L}$, with a glycerol conversion of $97 \%$. 


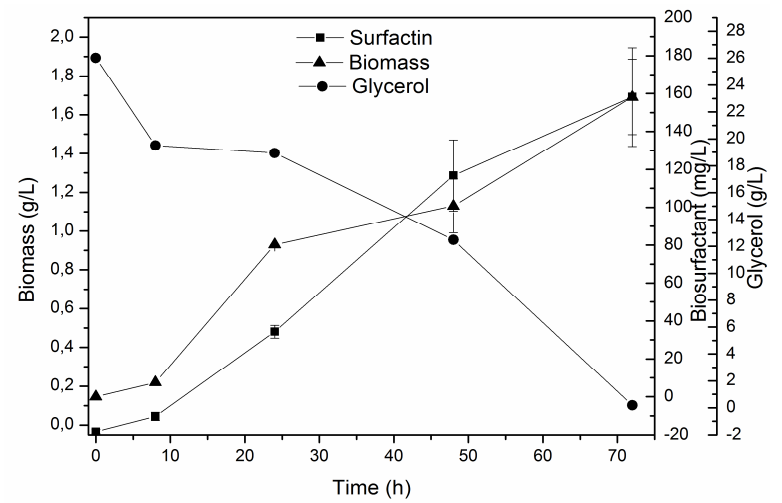

Figure 1 - Concentrations of biosurfactant, biomass and glycerol consumption by $B$. subtilis ATCC 6633 cultivated at $30^{\circ} \mathrm{C}$ and 180 rpm in mineral media supplemented with Glycerol.

\section{Surface activity of the biosurfactant produced by B. subtilis ATCC 6633 cultivated in mineral media supplemented with Glycerol.}

The surface activity of the biosurfactant was determined by measuring the surface tension, emulsifying activity and emulsion index of the supernatant from the batch culture of $B$. subtilis ATCC 6633. Figure 2 showed the results of surface tension of the cell-free fermented broth, which reached $31.5 \pm 1.6 \mathrm{mN} / \mathrm{m}$ after $72 \mathrm{~h}$ of fermentation. These results indicated that the microorganism tested demonstrated ability to produce biosurfactant since the effectiveness of a surfactant was determined by its ability to reduce the surface and interfacial tensions. According to Gudina et al. (2010), a good surfactant reduces the surface tension of water from 72.0 to $35.0 \mathrm{mN} / \mathrm{m}$, and the interfacial tension between water and hexadecane from 40.0 to $1.0 \mathrm{mN} / \mathrm{m}$.

Emulsifying properties of biosurfactants produced by $B$. subtilis ATCC 6633 cultivated in mineral media supplemented with glycerol were determined by measuring the emulsifying activity, which determined the ability of biosurfactant in forming oil-water emulsion, and emulsifying index, which determined the capacity of surfactant in forming emulsions on different hydrophobic substrates (soybean oil, kerosene and nhexadecane). Results of Figure 3 showed that higher and more stable emulsification activities, between 2 and 3 units, were detected when soilbean oil was used as hydrophobic compoud. These results were superior to those described for the synthetic commercial surfactants tested by Amaral et al. (2006). They were also superior to those described to other biosurfactants from Yarrowia lipolytica (Amaral et al. 2006), C. lipolytica IA (Sarubbo et al. 2001) and Nocardia sp. L-417 (Kim et al. 2000). Regarding emulsifying index, best result of E24 was obtained by using $\mathrm{n}$-hexadecane $(53.3 \%)$, followed by soybean oil (43.3\%). No measurable emulsifying index was obtained when kerosene was used.

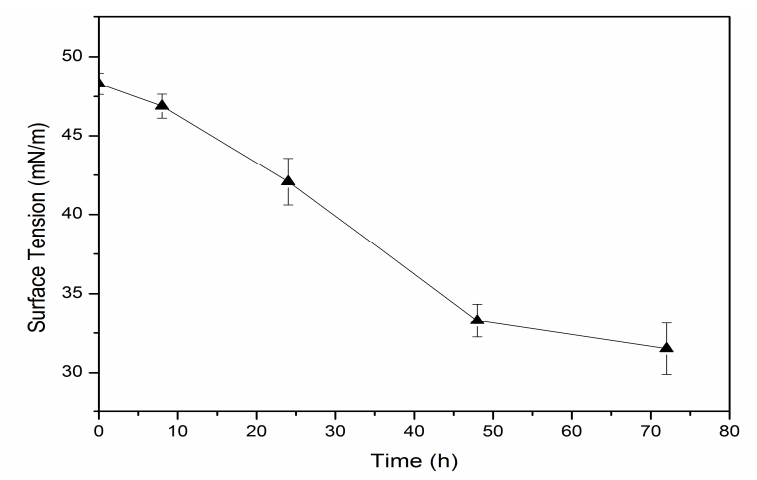

Figure 2 - Surface tension of the cell-free fermented broth during cultivation of $B$. subtilis ATCC 6633 at $30^{\circ} \mathrm{C}$ and $180 \mathrm{rpm}$ in mineral media supplemented with Glycerol.

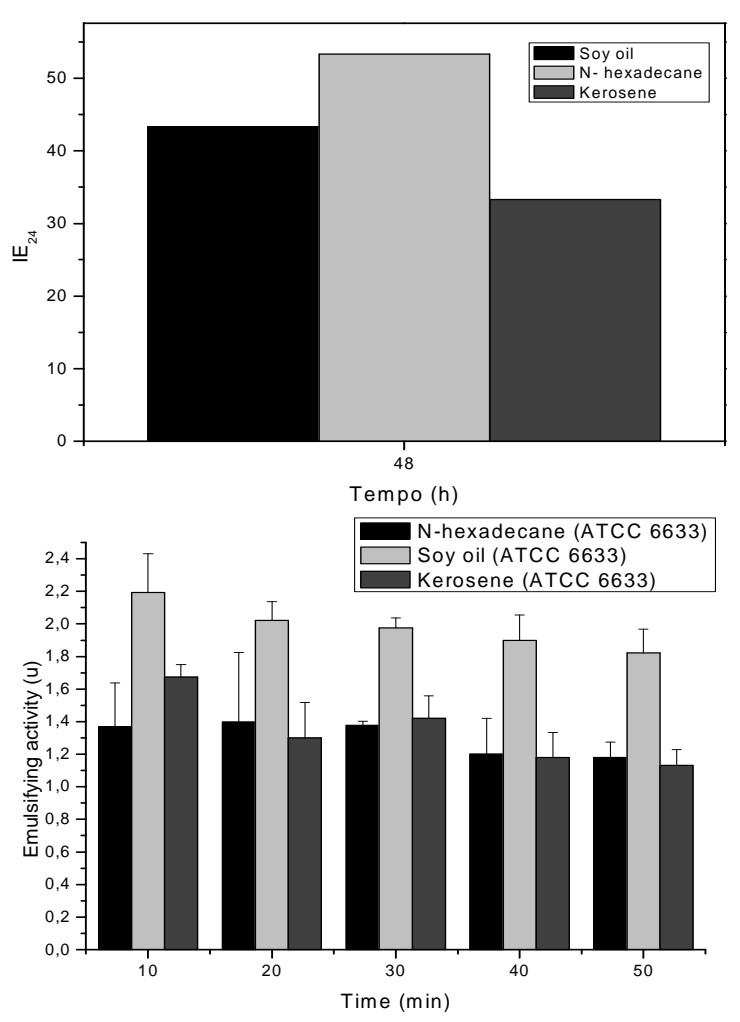

Figure 3 - Emulsifying activity and emulsification index $\left(\mathrm{I}_{\mathrm{E} 24}\right)$ of the biosurfactant produced by Bacillus subtilis ATCC 6633, after $48 \mathrm{~h}$ of fermentation at $30^{\circ} \mathrm{C}$ and $180 \mathrm{rpm}$, against $\mathrm{N}-\mathrm{Hexadecane}$, soy bean oil and kerosene. 


\section{Critical micelle concentration and minimum surface tension}

In order to determine the critical micelle concentration of the crude surfactant produced by B. subtilis ATCC 6633 grown in a mineral media containing glycerol as carbon source, the relationship between the surface tension and surfactin concentration was determined (Fig. 4A). There was a progressive decrease in surface tension with increasing concentrations of surfactin. For biosurfactant concentrations higher than $30 \mathrm{mg} / \mathrm{L}$, the surface tension became stable and no appreciable reduction was observed even for the highest concentrations tested. A semilogarithm plot of surface tension versus surfactin concentration allowed determining the $\mathrm{CMC}$ value as $33.6 \mathrm{mN} / \mathrm{m}$. A minimum surface tension value of $32.3 \mathrm{mN} / \mathrm{m}$ was obtained at a surfactin concentration of $71.9 \mathrm{mg} / \mathrm{L}$.

Table 1 shows the CMC of SDS and several biosurfactant isolated from different B. subtilis strains. As observed these compounds could reduce the surface tension of water to values around $30-35 \mathrm{mN} / \mathrm{M}$ and the $\mathrm{CMC}$ of the biosurfactants ranged from 1-2000 $\mathrm{mg} / \mathrm{L}$ (Sobrinho 2007). By comparison, the results obtained in this work were in agreement with those obtained from the literature, which showed the potential of using glycerol as a carbon source for surfactin production by B. subtilis strains.

Table 1 - Minimal surface tensions and critical micelle concentration (CMC) obtained for several surface active compounds.

\begin{tabular}{lcll}
\hline \multicolumn{1}{c}{ Surfactant } & $\begin{array}{c}\text { Surface } \\
\text { Tension } \\
(\mathbf{m N} / \mathbf{M})\end{array}$ & $\begin{array}{c}\text { CMC } \\
(\mathbf{m g} / \mathbf{L})\end{array}$ & \multicolumn{1}{c}{ Reference } \\
\hline SDS (Synthetic) & 33.7 & 270.0 & Hirata et al. 2009 \\
Surfactin & 27.5 & 150.0 & Fox and Bala(2000) \\
Surfactin & 28.7 & 78.6 & $\begin{array}{l}\text { Reis et al. (2004) } \\
\text { Surfactin/fengycin }\end{array}$ \\
& 27.0 & 40.0 & $\begin{array}{l}\text { Sivapathasekaran } \\
\text { et al. 2010 }\end{array}$ \\
Crude lipopeptide & 29.1 & 140.0 & Mukherjee et al. 2005 \\
\hline
\end{tabular}

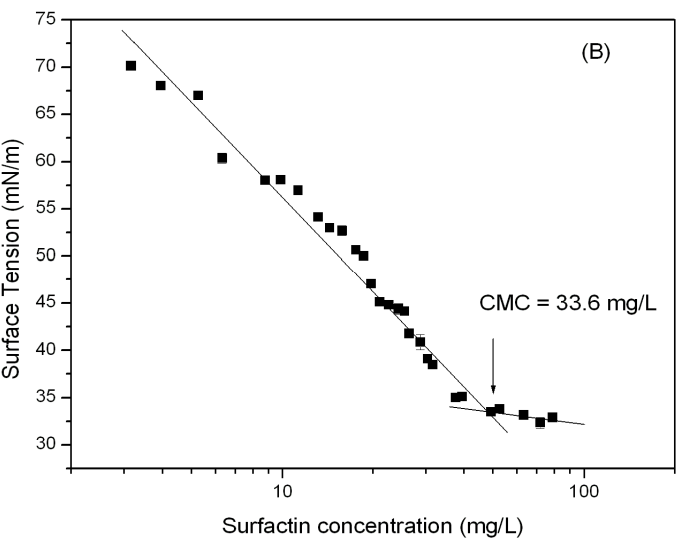

Figure 4 - Influence of surfactin concentration on the surface tension of the cell-free fermented broth. (A) Surface tensin of the crude surfactin produced by B. subtilis ATCC 6633 after 48 hours of fermentation at $30^{\circ} \mathrm{C}$ and $180 \mathrm{rpm}$. (B) Surface tension as a function of the logarithm of surfactin concentration. The reference surface tension value was $72 \mathrm{mM} / \mathrm{m}$.

\section{CONCLUSIONS}

Bacillus subtilis ATCC 6633 was able to grow and produce surfactin in the medium formulated with crude glycerol, reaching $158.14 \mathrm{mg} / \mathrm{L}$ of biosurfactant and lowering the surface tension of the cell-free fermented broth to $31.5 \pm 1.6 \mathrm{mM} / \mathrm{m}$ after $72 \mathrm{~h}$ of fermentation. Bacterial growth in mineral medium supplemented with residual glycerol yielded a biosurfactant with an E24 of n- hexadecane $(53.3 \%)$, followed by soybean oil (43.3\%). The emulsifying activity was high and stable when soybean oil was used as hydrophobic compound. The minimum surface tension and the critical micelle concentration of the biosurfactant produced by B. subtilis ATCC 6633 in this work were similar to the results previously reported for biosurfactants produced by the same strain using different substrates. The results indicated that glycerol could be a suitable substrate for the development of a cost-effective bioprocess for 
biosurfactant production. Nevertheless, in order to achieve a commercially competitive bioproduct, it is still necessary to increase the production yield, which may be achieved by optimizing some operational parameters, such as $\mathrm{pH}$, temperature and aeration rate.

\section{ACKNOWLEDGMENTS}

The authors thank $\mathrm{CNPq}$ and CAPES for the financial support that made this work possible.

\section{REFERENCES}

Amaral PFF, Silva JM, Lehock M, Barros-Timmons AMV, Coelho MAZ, Marrucho IM, Coutinho JAP. Production and characterization of a bilemulsifier from Yarrowia lipolytica. Process Biochem. 2006; 41: 1894-1898.

Bicca FC, Fleck CL, Ayub MAZ. Production of biosurfactant by hydrocarbon degrading Rhodococcus rubber and R. Erythropolis. Microbiol Rev. 1999; 30: 231-2369.

Cameotra SS, Makkar RS. Synthesis of biosurfactants in extreme conditions. Appl Microbiol Biotechnol. 1998; 50: 520-529.

Cirigliano MC, Carman GM. Isolation of a Bioemulsifier from Cândida lipolytic. Appl Environ Microbiol. 1984; 48: 747-750.

Cirigliano MC, Carman GM. Purification and characterization of liposan, a bioemulsifier from Candida lipolytica. Appl Environ Microbiol. 1985; 50: 846-850.

Cooper DG, Goldenberg BG, Surface-ative agentes from two Bacillus species. Appl Environ Microbiol. 1987; 53: 224-229.

Davis DA, Lynch HC, Varley J. The production of surfactin in batch culture by Bacillus Subtilis ATCC 21332 is strongly influenced by the conditions of nitrogen metabolism. Enzyme Microbial Technol. 1999; 25: 322-329.

Desai JD, Banat IM. Microbial production of surfactants and their commercial potential. Microbiol Mol Rev. 1997; 61: 47-64.

Fiechter A. Biosurfactants: Moving towards industrial applications. Trends Biotechnol. 1992; 10: 208-217.

Fox SL, Bala GA. Production of surfactant from Bacillus subtilis ATCC 21332 using potato substrates. Bioresource Technol. 2000; 75: 235-240.

Giro MEA, Martins JJL, Rocha MVP, Melo VMM, Gonçalves LRB. Clarified Cashew apple juice as alternative raw material for biosurfactant production by Bacillus subtilis in a batch bioreactor. Biotechnol J. 2009; 4:738-747.
Gudina EJ, Teixeira JA, Rodrigues LR. Isolation and functional characterization of a biosurfactant produced by Lactobacillus paracasei. Colloids Surfaces B. 2010; 76: 298-304.

Guerra-Santos LH, Kapeli O, Fiechter A. Pseudomonas aeruginosa biosurfactant production in continuous culture with glucose as carbon source. Appl Microbiol Biotechnol. 1984; 48: 301-305.

Hirata Y, Ryu M, Oda Y, Igarashi K, Nagatsuka A, Furuta T, Sugiura M. Novel characteristics of sophorolipids, yeast glycolipid biosurfactants, as biodegradable low-foaming surfactants. J Biosci Bioeng. 2009; 108: 142-146.

Kim SH, Lim EJ, Lee SO, Lee JD, Lee TH. Purification and characterization of biosurfactants from Nocardia sp. L-417. Biotechnol Appl Biochem. 2000; 31: 249253.

Kim SH, Lim EJ, Lee SO, Lee JD, Lee TH. Purification and characterization of biosurfactants from Nocardia sp. L-417. Biotechnol Appl Biochem. 2002; 31: 249253.

Makkar RS, Cameotra SS. Effects of Various Nutritional Supplements on Biosurfactant Production by a Strain of Bacillus subtilis. J Surfactants Deterg. 2002; 5: 11-17.

Makkar RS, Comeotra SS. Production of biosurfactant at mesophilic and thermophilic conditions by a strain of Bacillus subtilis. J Ind Microbiol Biotechnol. 1998; 20: 48-52.

Mukherjee AK, Das K. Correlation between diverse cyclic lipopeptides production and regulation of growth and substrate utilization by Bacillus subtilis strains in a particular habitat. FEMS Microbiol Ecol. 2005; 54: 479-489.

Neves LCM, Oliveira KS, Kobayashi MJ, Penna TCV, Converti A. Biosurfactant Production by Cultivation of Bacillus atrophaeus ATCC 9372 in Semidefined Glucose/Casein-Based Media. Appl Biochem Biotechnol. 2007; 137-140: 539-54.

Nitschke M, Pastore GM. Biossurfactantes: Propriedades e aplicações. Quim Nova. 2002; 25: 772-776.

Pruthi V, Cameotra SS. Production and properties of a biosurfactant synthesized by Arthrobacter Protophormiae - An Antarctic Strain. World J Microbiol Biotechnol. 1997; 13: 137-139.

Reis FASL, Sérvulo EFC, Franc $\square$ a FP. Lipopeptide surfactant production by Bacillus subtilis grown on low-cost raw materials. Appl Biochem Biotechnol. 2004; 115: 899-912.

Salihu A, Abdulkadir I, Almustapha MN. An investigation for potential development on biosurfactants. Biotechnol Mol Biol Rev. 2009; 4: 111-117. 
Santa Anna LM, Sebastian GV, Menezes EP, Alves TLM, Santos AS, Pereira Jr. N, Freire DMG. Production of Biosurfactants from Pseudomonas aeruginosa PA1 Isolated in Oil Environments. Braz J Chem Eng. 2002; 19: 159-166.

Sar N, Rosenberg E. Emulsifier production by Acinetobacter calcoaceticus strains. Curr Microbiol. 1983; 9: 309-314.

Sarubbo LA, Marçal MCR, Neves MLC, Silva MPC, Porto ALF, Campos-Takaki GM. Bioemulsifer production in batch culture using glucose as carbon source by Candida lipolytica. Appl Biochem Biotechnol. 2001; 95:59-67.

Sivapathasekaran C, Das P, Mukherjee S, Saravanakumar J, Mandal M, Sen R. Marine Bacterium Derived Lipopeptides: Characterization and Cytotoxic Activity Against Cancer Cell Lines. Int J Pept Res Ther. 2010; 16: 215-222.

Sobrinho HBS. Utilização de resíduos industriais como substrato de baixo custo para a produção de biossurfactante por Candida sphaerica [PhD Thesis]. Recife: Universidade Católica de Pernambuco; 2007.
Sousa M, Melo VMM, Rodrigues S, Santana HB, Gonçalves LRB. Screening of biosurfactantproducing Bacillus strains using glycerol from the biodiesel synthesis as main carbon source. Bioproc Biosystems Eng. 2012; 35: 897-906.

Thompson JC, He BB. Characterization of crude glycerol from biodiesel production from multiple feedstocks. Appl Eng Agric. 2006; 22: 261-265.

Van Dyke MI, Lee H, Trevors JT. Applications of microbial surfactants. Biotechnol Adv. 1991; 9: 241252.

Yeh M S, Wei YH, Chang JS. Enhanced production of surfactin from Bacillus subtilis by addition of solid carriers. Biotechnol Progress. 2005; 21: 1329-1334.

Zajic JE, Seffens W. Biosurfactants. Crit Rev Biotechnol. 1984; 1: 87-107. 